\title{
Rhamnus alaternus aqueous extract enhances the capacity of system redox defence and protects hepatocytes against aluminum chloride toxicity in rats
}

\author{
Chahrazed Benzaid ${ }^{1,2}$, Lazhari Tichati ${ }^{3}$, Fouzia Trea ${ }^{3}$, Mahmoud Rouabhia ${ }^{2}$ and Kheireddine Ouali ${ }^{3 *}$ (D)
}

\begin{abstract}
Background: This study was designed to evaluate the protective effects of a Rhamnus alaternus aqueous extract (RAAE) on aluminum chloride-induced hepatotoxicity in rats. A preliminary phytochemical study and antioxidant activity tests of the extract were performed.
\end{abstract}

Methods: A preliminary phytochemical study and antioxidant activity tests of the extract were performed. For the in vivo study, twenty-four male rats were divided into four groups. The control group (C); the RAAE group treated with $250 \mathrm{mg} / \mathrm{kg}$ b.w RAAE; the $\mathrm{AlCl}_{3}$ group, which received $50 \mathrm{mg} / \mathrm{kg}$ b.w $\mathrm{AlCl}_{3}$; and the $\mathrm{AlCl}_{3} / \mathrm{RAAE}$ group that was treated with $\mathrm{AlCl}_{3}$ plus RAAE.

Results: The RAAE contains several phenolic compounds. This plant extract showed a high radical scavenging effect and high antioxidant activity. Administration of $\mathrm{AlCl}_{3}$ resulted in a significant increase in the activities of aspartate aminotransferase and alanine aminotransferase (AST, ALT), alkaline phosphatase (ALP), and lactate dehydrogenase $(\mathrm{LDH})$ and significant decreases in the plasma concentrations of total proteins and albumin. Moreover, $\mathrm{AlCl}_{3}$ induced a hepatic pro-oxidant effect leading to an increase in malonaldehyde (MDA) and carbonyl protein contents, the depletion of the content of reduced glutathione (GSH) and a decrease in the antioxidant enzymatic activities of superoxide dismutase (SOD), catalase (CAT) and glutathione peroxidase (GPX). However, RAAE supplementation with $\mathrm{AlCl}_{3}$ treatment significantly decreased the levels of MDA and carbonyl proteins and markedly restored the activities of the antioxidant enzymes. These results are supported by the improvement in liver tissue restoration.

Conclusions: The Rhamnus alaternus aqueous extract was shown to have effective antioxidant activity owing to its phenolic compounds protecting against $\mathrm{AlCl}_{3}$-induced liver oxidative damage.

Keywords: Aluminum Chloride, Rhamnus alaternus Aqueous Extract, Oxidative Stress, Antioxidant, Hepatotoxicity, Rat

\footnotetext{
* Correspondence: kheireddine.ouali@univ-annaba.dz

3 Laboratory of Environmental Biosurveillance (LBSE), Department of Biology, Faculty of Sciences, Badji Mokhtar University, BP 12 Sidi Amar, 23000 Annaba, Algeria

Full list of author information is available at the end of the article
}

\section{Springer Open}

(c) The Author(s). 2021 Open Access This article is licensed under a Creative Commons Attribution 4.0 International License, which permits use, sharing, adaptation, distribution and reproduction in any medium or format, as long as you give appropriate credit to the original author(s) and the source, provide a link to the Creative Commons licence, and indicate if changes were made. The images or other third party material in this article are included in the article's Creative Commons licence, unless indicated otherwise in a credit line to the material. If material is not included in the article's Creative Commons licence and your intended use is not permitted by statutory regulation or exceeds the permitted use, you will need to obtain permission directly from the copyright holder. To view a copy of this licence, visit http://creativecommons.org/licenses/by/4.0/. 


\section{Introduction}

Aluminum ( $\mathrm{Al})$ is a ubiquitous metal found in our daily life due to its presence in the natural environment and its large use in food, cosmetic products, and water purification and for therapeutic purposes [1, 2]. Human tissues such as the skin, respiratory tract and intestine are barriers to $\mathrm{Al}$ entry into the blood. However, $\mathrm{Al}$ contamination can occur through fluids given parenterally [3]. Inappropriate levels of $\mathrm{Al}$ in the human body could cause serious health safety problems [4, 5], and aluminum may accumulate in the liver [6], kidneys [7] and brain [8]. It has been reported that the presence of $\mathrm{Al}$ in these organs causes damage through the generation of reactive oxygen species [9]. ROS can induce the oxidation of cell macromolecules (lipids, proteins, and nucleic acids) and alter the normal redox status of the cell $[10,11]$. The liver is a vital metabolic organ that is able to maintain energy levels, metabolize xenobiotics and ensure the structural stability of the body [12]. Liver dysfunction or failure usually leads to health disorders [13]. Al can affect the liver by causing a loss in redox homeostasis, which consequently leads to pro-/antioxidant imbalance resulting in the production of high levels of $\operatorname{ROS}[9,14]$. Al hepatotoxicity is associated with histopathological alterations, including cell necrosis and increased inflammatory cell infiltration $[15,1]$. $\mathrm{Al}$ intoxication treatment is performed with the chelating agent deferoxamine or malic acid [16, 17]. Experimental studies have suggested that the use of antioxidants and free radical scavengers such as selenium, melatonin, boric acid, and vitamin $\mathrm{C}$ can prevent the deleterious effects of free radicals produced as a result of $\mathrm{Al}$ intoxication [18, 19]. Plant extracts may ameliorate the toxicosis caused by $\mathrm{Al}$ exposure, as they contain several antioxidant molecules [20, 21]. One plant used against $\mathrm{Al}$ toxicosis could be Rhamnus alaternus L. This shrub belongs to the Rhamnaceae family, known under the non-vernacular of Nerprun and Tamazight Amliles. It is widely used in popular medicine for its digestive, diuretic, laxative, astringent, and hypotensive activities and for treating hepatic (jaundice) and dermatological complications [22]. Previous studies have shown that the crude extract of $R$. alaternus has multiple biological properties, including antioxidant, anti-mutagenic, antiproliferative, antigenotoxic [23-25], and antimicrobial properties, and it is rich in polyphenols [26] and flavonoids [27]. Therefore, the present study aimed to investigate the protective antioxidant effects of the $R$. alaternus aqueous extract against subchronic exposure to aluminum chloride-induced oxidative hepatotoxicity in rats.

\section{Materials and methods}

\section{Chemicals and reagents}

Reagent grade $98 \%$ pure aluminum chloride $\left(\mathrm{AlCl}_{3}\right)$, the Folin-Ciocalteu phenol reagent, catechin, the free stable radical 1,1-diphenyl-2-picrylhydrazyl (DPPH), butylated hydroxytoluene, thiobarbituric acid (TBA), reduced glutathione (GSH), and DTNB [5,5'-dithiobis-2-nitrobenzoic acid] were purchased from Sigma Chemical Co. (St. Louis, France).

\section{Plant materials}

The study was conducted on the aerial parts of $R$. alaternus plant leaves and stems that were collected in February 2019 from the town of Tigzirt (Tizi-Ouzou city, Northeast Algeria).

The aerial parts (leaves and stems) were cleaned with distilled water, dried in the dark, and then pulverized in a mechanical grinder to obtain a fine powder. The aqueous extract of $R$. alaternus leaves was prepared by the decoction method [28]. Briefly, $500 \mathrm{~g}$ of plant powder was used in a flask containing $2000 \mathrm{ml}$ of distilled water, and the decoction continuously refluxed for two hours.

Thereafter, the decoct was filtered through Whatman No. 1 filter paper, centrifuged at $2500 \mathrm{~g}$ for $5 \mathrm{~min}$, and evaporated in vacuo using rotary evaporator rotavapor. The residue was collected, weighed to determine the yield, and then maintained under sterile conditions at $-20{ }^{\circ} \mathrm{C}$ until use.

\section{Determination of total phenolic compounds}

The determination of total polyphenol content was performed by the Folin-Ciocalteu colorimetric method as described elsewhere [29]. The concentration of the total polyphenols was determined from the linear regression equation of the calibration curve with gallic acid: $\mathrm{Y}=$ $0.0138 x+0.0352, R^{2}=0.9927$, and expressed as micrograms of gallic acid equivalents (GE) per milligram of extract ( $\mu \mathrm{g} \mathrm{GE} / \mathrm{mg}$ of extract).

\section{Determination of total flavonoids}

Quantification of the flavonoids in the extract was performed by the aluminum trichloride method as described by Pourmorad et al. [30]. The level of flavonoids was deduced from the calibration curve of quercetin $\left(\mathrm{Y}=0,0111 \mathrm{x}+0.0116, \mathrm{R}^{2}=0,994\right)$ and expressed as micrograms of quercetin equivalents (QE) per milligram of extract ( $\mu \mathrm{g} \mathrm{QE} / \mathrm{mg}$ of extract).

\section{Determination of condensed tannins}

The contents of condensed tannins were determined by the acidic vanillin method [31]. The level of condensed tannins was deduced from the calibration curve of catechin (standard solution) according to the equation $\mathrm{Y}=0.0111 \mathrm{x}+0.0741, \quad \mathrm{R}^{2}=0.9847, \quad$ and expressed as micrograms of catechin equivalents (CE) per milligram of extract ( $\mu \mathrm{g} \mathrm{CE} / \mathrm{mg}$ of extract).

\section{DPPH radical scavenging activity}

The anti-free radical activity of $R$. alaternus plant extract was evaluated by a 1,1-diphenyl-2-picrylhydrazyl (DPPH) 
trapping test. Of note, DPPH is defined as a relatively stable free radical [32]. The antioxidant activity, indicating the free-radical scavenging ability of the extract, is expressed as the percent DPPH discoloration according to the following equation: $A A(\%)=[(A b s$ Control $-A b s$ sample) $/ A b s$ control] $\times 100$. $A \boldsymbol{A}(\%)$ refers to the antioxidant activity of DPPH and $A \boldsymbol{b}$ s refers to the absorbance at $517 \mathrm{~nm}$.

\section{Reducing power assay}

The reducing power of the extract was determined according to the method of Pan et al. [33] based on the chemical reduction of $\mathrm{Fe}^{3+}$ in the complex $\mathrm{K}_{3} \mathrm{Fe}$ $(\mathrm{CN})_{6}$ to form $\mathrm{Fe}^{2+}$.

\section{$\beta$-carotene bleaching assay}

The ability of the $R$. alaternus aqueous extract to prevent $\beta$-carotene bleaching was determined according to the method of Ismail et al. [34]. The antioxidant activity (AA \%) is expressed as an inhibition percent in relation to the negative control using the following equation:

$$
\begin{aligned}
\boldsymbol{A A} \%= & {[\mathbf{1}-(\boldsymbol{A t} \mathbf{0}-\boldsymbol{A t 1 2 0}) \text { test } /(\boldsymbol{A t 0}-\boldsymbol{A t 1 2 0}) \text { control }] } \\
& \times 100,
\end{aligned}
$$

where $\boldsymbol{A} \boldsymbol{t}_{\boldsymbol{o}}$ refers to the absorbance at time zero, and $A t_{120}$ refers to the absorbance at $120 \mathrm{~min}$.

\section{Animal studies}

Twenty-four male Wistar albino rats weighing $220 \pm 2 \mathrm{~g}$ were obtained from Pasteur Institute (Algiers, Algeria). They were kept in the animal house of our institution (Department of Biology, Badji-Mokhtar, Annaba University) under an adequate atmosphere: a temperature of $22{ }^{\circ} \mathrm{C} \pm 2{ }^{\circ} \mathrm{C}$, a $12 \mathrm{~h} / 12 \mathrm{~h}$ light/dark cycle, and stable hygrometry. Animals were provided free access to water and an energetically balanced and healthy diet (ONAB; Bejaia, Algeria).

\section{Study design}

After two weeks of adaptation, the animals were equally divided into four main groups and then subjected to various treatments for four weeks. Each treatment consisted of the delivery of one millilitre of the appropriate solution through daily gavage.

Group 1 (control group): rats received distilled water; Group 2 (RAAE): rats were orally administered $250 \mathrm{mg}$ of $R$. alaternus aqueous extract (RAAE) per $\mathrm{kg}$ body weight (b.w); Group $3\left(\mathrm{AlCl}_{3}\right)$ : rats were orally administered $50 \mathrm{mg} \mathrm{AlCl}_{3} / \mathrm{kg}$ b.w; Group $4\left(\mathrm{AlCl}_{3}+\mathrm{RAAE}\right)$ : rats received combined treatment $\left(50 \mathrm{mg} \mathrm{AlCl}_{3}+250 \mathrm{mg}\right.$ RAAE/kg b.w).

The selected doses of RAAE and $\mathrm{AlCl}_{3}$ were determined from what has been previously used in other studies [28] and |35]. All experimental procedures were performed according to international guidelines for the care and use of laboratory animals [36]. After the treatment period ( 4 weeks), the rats were sacrificed by decapitation, and blood samples were collected into heparin tubes followed by $10 \mathrm{~min}$ of centrifugation at $4000 \mathrm{~g}$ and $4{ }^{\circ} \mathrm{C}$ for biochemical analyses. Additionally, the liver of each animal was removed, weighed, and divided into two pieces: one piece was placed in buffered formalin for histological examination, and the other piece was kept in a $-80{ }^{\circ} \mathrm{C}$ freezer until antioxidant marker analysis.

\section{Biochemical parameters}

The plasma biochemical parameters (total proteins, albumin, transaminases (AST, ALT), alkaline phosphatase (ALP), total bilirubin, gamma-glutamyl transferase $(\gamma-$ GGT), and lactate dehydrogenase (LDH)) were determined by kinetic-colorimetric methods using commercially available kits from SpinReact (Spain).

\section{Homogenate preparation}

Liver samples were homogenized in the presence of phosphate-buffered saline. Briefly, $1 \mathrm{~g}$ of liver tissue was ground, homogenized in $2 \mathrm{ml}$ of phosphate buffer $(1 / 2$ w/v; $1 \mathrm{~g}$ tissue with $2 \mathrm{ml} \mathrm{PBS}, \mathrm{pH}=7,4)$, and then centrifuged at $10,000 \mathrm{~g}$, and $4{ }^{\circ} \mathrm{C}$ for $15 \mathrm{~min}$. The obtained supernatant was used for the determination of the malondialdehyde (MDA), reduced glutathione (GSH), protein carbonyl (PCO), and protein levels. We also measured SOD, GPx, and CAT enzymatic activities using the collected supernatants.

\section{Non-enzymatic antioxidant parameters}

The hepatic reduced glutathione (GSH) content was assayed according to the method of Ellman modified by Jollow et al. [37]. The hepatic malondialdehyde (MDA) content was determined following the method of Buege and Aust [38]. The level of carbonyl proteins (CPO) was measured by the method of Levine et al. [39], and the level of hepatic proteins was determined according to the method of Bradford [40] using Coomassie blue reagent.

\section{Enzymatic antioxidant activity parameters}

The enzymatic activity of dismutase (SOD) was determined according to the method of Beyer and Fridovich [41]. Glutathione peroxidase (GPx) and catalase (CAT) were determined according to the protocols outlined by Flohe and Gunzler [42] and Aebi [43], respectively.

\section{Histopathological examination}

Histological study of the liver was performed according to the routine technique described by Hould [44]. In 
brief, liver tissue specimens of each animal were fixed in $10 \%$ buffered formalin solution for $24 \mathrm{~h}$, dehydrated, and embedded in paraffin. Thereafter, the liver sections were sliced into $5 \mu \mathrm{m}$ thick sections, mounted on slides, stained with haematoxylin-eosin and subjected to light microscopy (LEICA DM, 1000) observation.

\section{Statistical study}

Experiments were performed with three repetitions in a fully randomized design and are displayed as the mean \pm SEM. Comparisons of multiple groups were analysed for statistical significance by one-way analysis of variance (ANOVA) with Tukey's post hoc test. Statistical tests were conducted using GraphPad Prism (Ver 7, California, USA), where $p<0.05$ was considered significant.

\section{Results}

Yield and total phenolic, flavonoid and tannin contents of the RAAE

Following phytochemical screening analyses, we determined that the yield of the aqueous extract of $R$. alaternus was $15,73 \%$ (Table 1 ). The level $/ \mathrm{mg}$ of dry extract for polyphenols was $64.11 \mu \mathrm{g} \mathrm{GE} / \mathrm{mg}$ of extract; for flavonoids, this value was $12.62 \mu \mathrm{g} \mathrm{QE} / \mathrm{mg}$ of extract; and for tannins, it was $8.39 \mu \mathrm{g} \mathrm{CE} / \mathrm{mg}$ of extract (Table 1 ).

\section{Antioxidant activity of RAAE}

As shown in Table 2, the aqueous extract of $R$. alaternus had a marked free-radical scavenging effect by DPPH assay with an $\mathrm{IC}_{50}$ value of $60.08 \mu \mathrm{g} / \mathrm{ml}$. The standard antioxidants ascorbic acid and $\mathrm{BHT}$ showed $\mathrm{IC}_{50}$ values of $7.24 \mu \mathrm{g} / \mathrm{ml}$ and $37.85 \mu \mathrm{g} / \mathrm{ml}$, respectively. Additionally, the aqueous extract exhibited a reducing iron power $\left(\mathrm{EC}_{50}=43.06 \mu \mathrm{g} / \mathrm{ml}\right)$ that was superior to that of BHT $(56.13 \mu \mathrm{g} / \mathrm{ml})$, and the extract's inhibition of $\beta$-carotene oxidation showed an $\mathrm{IC}_{50}$ of approximately $52.34 \mu \mathrm{g} / \mathrm{ml}$.

\section{Effect of treatment on hepatic functional biochemical markers}

Data related to the effects of the treatments on the variation in biochemical parameters of hepatic function are reported in Table 3. Treatment with $\mathrm{AlCl}_{3}$ caused a significant decrease $(p<0.05)$ in the plasma concentrations of total proteins and albumin compared to the control. In addition, the level of total bilirubin and the enzymatic activities of AST, ALP, LDH, ALT, and $\gamma$-GT increased in the $\mathrm{AlCl}_{3}$-treated group compared to the control group (Table 3). Interestingly, co-administration of RAAE to rats attenuated the hepatic biochemical alterations observed in rats receiving $\mathrm{AlCl}_{3}$ alone. Moreover, the co-treatment group showed improvements in the enzymatic activity status, the plasma levels of total proteins and albumin levels.

\section{Effect of treatments on hepatic malondialdehyde and carbonyl proteins}

As shown in Fig. 1a and b, $\mathrm{AlCl}_{3}$ treatment caused depletion in hepatic antioxidant capacity, as evidenced by a significant increase (more than $49.67 \% ; p<0.01$ ) in MDA (lipid peroxidation marker) and CPO levels (+ $28.64 \%$; $p<0.01)$ compared to the control. However, the use of $R$. alaternus at the same time as $\mathrm{AlCl}_{3}$ significantly $(p<0.05)$ decreased lipid peroxidation, as the level of hepatic MDA decreased from 49.67 to $16.43 \%$ and the level of CPO decreased from 28.64 to $13.86 \%$ compared to $\mathrm{AlCl}_{3}$ treatment alone (Fig. 1).

\section{Effect of treatments on hepatic reduced glutathione content and antioxidant enzymes}

As shown in Fig. 2a, b, c and d, treatment with $\mathrm{AlCl}_{3}$ caused a highly significant $(p<0.01)$ decrease in the GSH content and enzymatic activities of SOD and GPx, and a significant $(p<0.05)$ decrease in catalase activity in liver homogenates compared to control rats. The use of Rhamnus R. alaternus extract alone had no adverse effects on hepatic GSH or the enzymatic activities of SOD, GPx, or catalase (CAT). Interestingly, coadministration of $\mathrm{RAAE}$ with $\mathrm{AlCl}_{3}$ restored the antioxidant enzymatic activities and GSH levels compared with $\mathrm{AlCl}_{3}$ alone.

\section{Histological evaluation}

The control group (Fig. $3 \mathrm{~A}$ and B) exhibited normal hepatic histological architecture characterized by a visible central vein and normal hepatocytes with granular cytoplasm. Histological analyses of hepatic tissues from rats fed the aqueous extract of $R$. alaternus showed no structural changes or cell damage (Fig. $3 \mathrm{C}$ and D). However, the $\mathrm{AlCl}_{3}$-treated group showed severe hepatic tissue alterations consisting of hepatic degeneration, sinusoidal dilatation with infiltration of mononuclear cells, dilated centrilobular veins, and cell necrosis

Table 1 Yield, total phenolic, flavonoid and tannins contents of RAAE

\begin{tabular}{llll}
\hline Extract & Yields $(\%)$ & $\begin{array}{l}\text { Total phenolics } \\
(\boldsymbol{\mu g} \text { GE/mg DE) }\end{array}$ & $\begin{array}{l}\text { Total flavonoids } \\
(\boldsymbol{\mu g} \text { QE/mg DE) }\end{array}$ \\
\hline RAAE & $15.73 \pm 0.22$ & $64.11 \pm 3.18$ & $12.62 \pm 0.85$ \\
\hline
\end{tabular}

Values are means of three replications \pm SEM

RAAE: R. alaternus aqueous extract; $\mathrm{GE}$, gallic acid equivalents; $\mathrm{QE}$, quercetin equivalents; $\mathrm{CE}$, catechin equivalents; $\mathrm{DE}$, dry extract 
Table 2 DPPH free radical scavenging activity, reducing power, and $\beta$-carotene bleaching inhibition of RAAE

\begin{tabular}{llll}
\hline Extract/Standard & $\mathrm{EC}_{\mathbf{5 0}}$ values $(\boldsymbol{\mu g} / \mathbf{m l})$ & & \\
\cline { 2 - 4 } & DPPH scavengingActivity & $\boldsymbol{\beta}$ - Carotenebleaching inhibition & Reducing power \\
\hline AA & $7.24 \pm 0.45$ & $\mathrm{NT}$ & $8.52 \pm 0.63$ \\
BHT & $37.85 \pm 1.12$ & $20.46 \pm 0.84$ & $56.13 \pm 1.22$ \\
RAAE & $60.08 \pm 2.09$ & $52.34 \pm 1.16$ & $43.06 \pm 1.90$ \\
\hline
\end{tabular}

Values are means of three replications \pm SEM; NT: Not tested

AA Ascorbic acid, BHT Butyl hydroxytoluene, RAAE R. alaternus aqueous extract; $\mathrm{EC}_{50}$ : Extract concentration corresponding to $50 \%$ of the antioxidant activity or 0.5 of absorbance in reducing power assay

(Fig. 3E, F and G). These adverse effects due to $\mathrm{AlCl}_{3}$ were almost restored after Rhamnus al $R$. alaternus extract treatment. There was also a decrease in the inflammatory response with the use of the $R$. alaternus extract (Fig. $3 \mathrm{H}$ and I).

\section{Discussion}

In this in vitro and in vivo (animal model) study, we demonstrated a possible protective effect of the $R$. alaternus aqueous extract (RAAE) against $\mathrm{AlCl}_{3}$-induced oxidative liver damage as previously reported [27]. The beneficial antioxidant properties of the $R$. Alaternus aqueous extract can be attributed to the phenolic compounds present, as previously reported for various plant extracts [25]. The $R$. alaternus extract we used in this study had strong DPPH freeradical scavenging activity, owing to its ability to provide hydrogen atoms [23] and is considered a primary antioxidant that is able to delay or inhibit $\beta$-carotene bleaching [45]. Additionally, its reducing power is a significant indicator of its potential antioxidant activity [46]. Moreover, sub-chronic aluminum chlorideexposed rats (50 mg/kg bw for 30 days) exhibited marked hepatotoxicity that manifested as a significant decrease in the levels of total proteins and albumin.
This can be attributed to the increased intracellular concentration of aluminum in the liver that caused a decrease in protein synthesis [35]. The inhibitory effects of $\mathrm{AlCl}_{3}$ on the protein profile demonstrated in this study are in accordance with those reported by Albendea et al. [47], who showed that proteins react with free radicals generated by $\mathrm{AlCl}_{3}$. These proteins can be denatured, fragmented, or lose their chemical structure, and thus, lose their biological activities. We demonstrated that the decrease in the levels of protein transporters is associated with liver tissue damage, as evidenced by a significant increase in AST, ALT and LDH activity. This finding could support the hepatic histopathological modifications found, resulting in leakage of liver enzymes into the bloodstream following alterations in cell membrane permeability $[48,14]$. Furthermore, increased enzymatic activity of alkaline phosphatase (ALP) in the blood generally describes primary liver biliary cirrhosis or an alteration of the hepatic architecture [49], since the rise in total bilirubin level might be due to erythrocyte haemolysis or disruption of hepatic function [2]. Remarkable $\mathrm{AlCl}_{3}$-induced alterations in biochemical parameters (decreased plasma concentrations of total proteins and albumin and increased AST, ALT and PAL activities) were confirmed by the

Table 3 Plasma hepatic function parameters

\begin{tabular}{|c|c|c|c|c|}
\hline \multirow[t]{2}{*}{ Parameters } & \multicolumn{4}{|c|}{ Experimental groups } \\
\hline & Control & Alcl3 & RAAE & Alcl3/RAAE \\
\hline $\mathrm{TP}(\mathrm{g} / \mathrm{dl})$ & $8.95 \pm 0.56$ & $7.08 \pm 0.38^{*}$ & $9.02 \pm 0.64^{\#}$ & $8.27 \pm 0.43$ \\
\hline $\operatorname{ALB}(\mathrm{g} / \mathrm{dl})$ & $5.23 \pm 0.28$ & $3.44 \pm 0.17^{*}$ & $5,32 \pm 0.26^{\#}$ & $4.57 \pm 0.20$ \\
\hline $\mathrm{TB}(\mathrm{mg} / \mathrm{L})$ & $01.05 \pm 0.07$ & $2.13 \pm 0.15^{* *}$ & $01.12 \pm 0.10^{\# \#}$ & $1.53 \pm 0.14^{*}$ \\
\hline AST (U/L) & $114.34 \pm 7.03$ & $146.53 \pm 9.64^{* *}$ & $111.09 \pm 6.75^{* *}$ & $123.43 \pm 6.12^{\#}$ \\
\hline ALT $(U / L)$ & $43.26 \pm 2.64$ & $56.23 \pm 3.17^{*}$ & $41.09 \pm 3.01^{\#}$ & $50.32 \pm 2.87$ \\
\hline $\mathrm{ALP}(\mathrm{U} / \mathrm{L})$ & $108.39 \pm 7.03$ & $168.05 \pm 11.92^{* *}$ & $113.12 \pm 5.36^{\# \#}$ & $135.60 \pm 8.35^{* \#}$ \\
\hline$\gamma-G T(U / L)$ & $02.13 \pm 0.12$ & $2.94 \pm 0.20^{*}$ & $02.10 \pm 0.09^{\# \#}$ & $02.45 \pm 0.16$ \\
\hline $\mathrm{LDH}(\mathrm{U} / \mathrm{L})$ & $538.12 \pm 31.95$ & $935.40 \pm 56.32^{* *}$ & $548.44 \pm 35.19^{\# \#}$ & $796 \pm 45.76^{*}$ \\
\hline
\end{tabular}

Data are expressed as mean \pm SEM ( $n=6$ rats/group)

Alcl3: Aluminum Chloride; RAAE: $R$. alaternus aqueous extract; TP: total protein; ALB: albumin;TB: total bilirubin; AST: aspartate transaminase; ALT: alanine

transaminase; ALP: alkaline phosphatase; $\gamma$-GT: gamma-glutamyltransferase; LDH: lactate dehydrogenase

Significant difference compared to the control group $\left({ }^{*} p>0.05,{ }^{* *} p>0.01\right)$

Significant difference compared to the AICl3 treated group (\#p>0.05, \#\#p>0.01) 

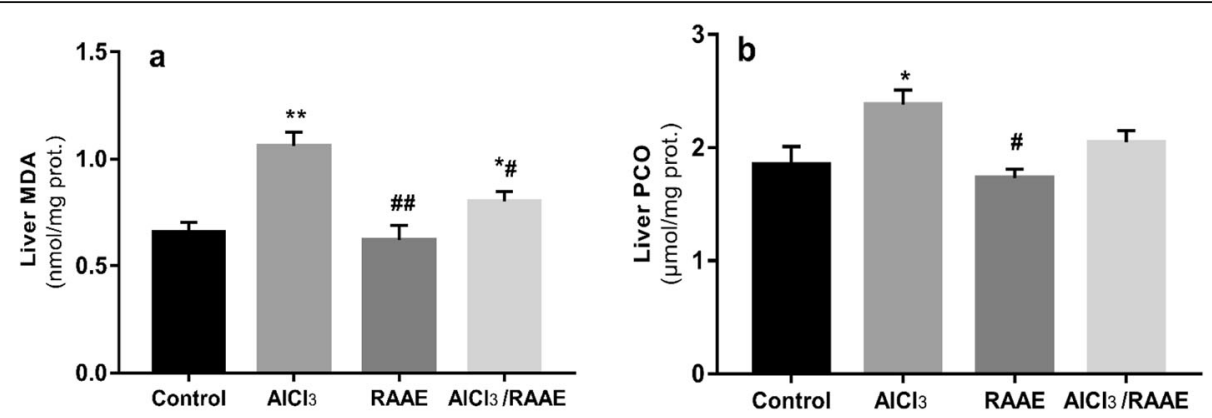

Fig. 1 Hepatic malondialdehyde (MDA) and carbonyl protein (PCO) levels in control and experimental groups. Data are expressed as mean \pm SEM ( $\mathrm{n}=6 \mathrm{rats} / \mathrm{group}$ ). $\mathrm{AlCl}_{3}$ : Aluminium Chloride; RAAE: R. alaternus aqueous extract; Significant difference compared to the control group ( ${ }^{*} p<0.05$, $\left.{ }^{* *} p<0.01\right)$; Significant difference compared to the $\mathrm{AlCl}_{3}$, Significant difference compared to the $\mathrm{AlCl}_{3}$ treated group $\left({ }^{\#} p<0.05,{ }^{\# \#} p<0.01\right)$

histopathological observations reported in this study, showing cell necrosis, tissue degeneration, sinusoidal dilatation, and congestion of the centrilobular vein. These results are in line with those previously reported [14, 21].

It should be noted that co-ingestion of RAAE and $\mathrm{AlCl} 3$ restored the levels of total proteins and albumin. RAAE decreased the activity of hepatic enzyme markers, contributing to the protection of the structural integrity of the hepatocellular membrane. The beneficial effects of RAAE could be attributed to the high level of phenolic compounds, including alkaloids and flavonoids [22, 27], confirming its effectiveness in preventing liver damage induced by various xenobiotics $[28,50]$.
We showed that the over-induction of oxidative stress due to $\mathrm{AlCl}_{3}$ intoxication is strengthened by our study of lipid peroxidation and protein carbonyls, which are correlated with decreased hepatic antioxidant enzyme activities. In addition, $\mathrm{AlCl}_{3}$ treatment caused alterations in the antioxidant status, resulting in a significant increase in the levels of MDA and $\mathrm{PCO}$, which reflects the oxidation of lipids and proteins shown previously $[10,51]$. We demonstrated that $\mathrm{AlCl}_{3}$ decreased the levels of hepatic glutathione (GSH), leading to a pro-/antioxidant imbalance, as previously reported $[35,14]$. Glutathione, an abundant tripeptide, plays a key role in detoxifying free radical species, maintaining the intracellular redox state, and
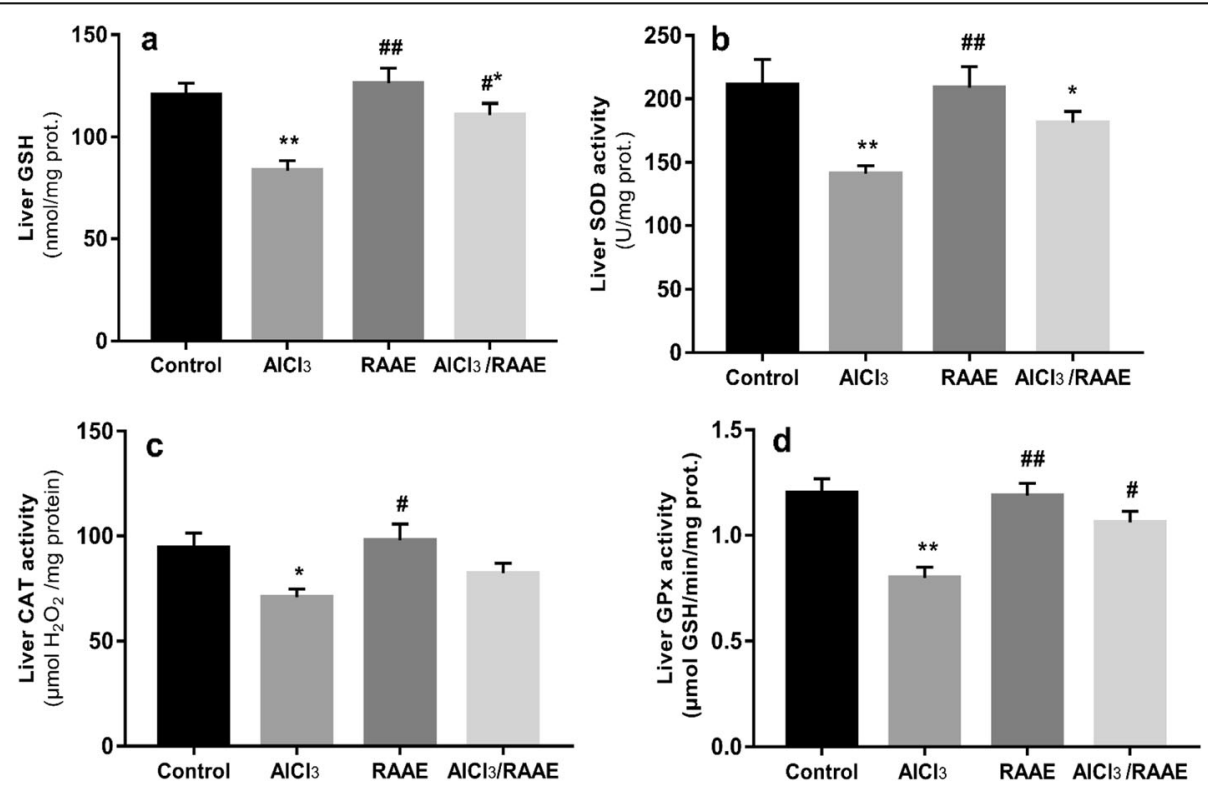

Fig. 2 Reduced glutathione content (a), and SOD (b), CAT(c), and GPX (d) activities in liver of control and experimental groups. Data are expressed as mean $\pm \mathrm{SEM}$ ( $n=6$ rats/group). AlCl ${ }_{3}$, Aluminium Chloride; RAAE, R. alaternus aqueous extract; GSH, reduced glutathione; SOD, superoxide dismutase; CAT, catalase; GPx, glutathione peroxidase. Significant difference compared to the control group $\left({ }^{* *} p<0.01,{ }^{*} p<0.05\right)$; Significant difference compared to the $\mathrm{AlCl}_{3}$ treated group $\left({ }^{\#} p<0.01,{ }^{\#} p<0.05\right)$ 

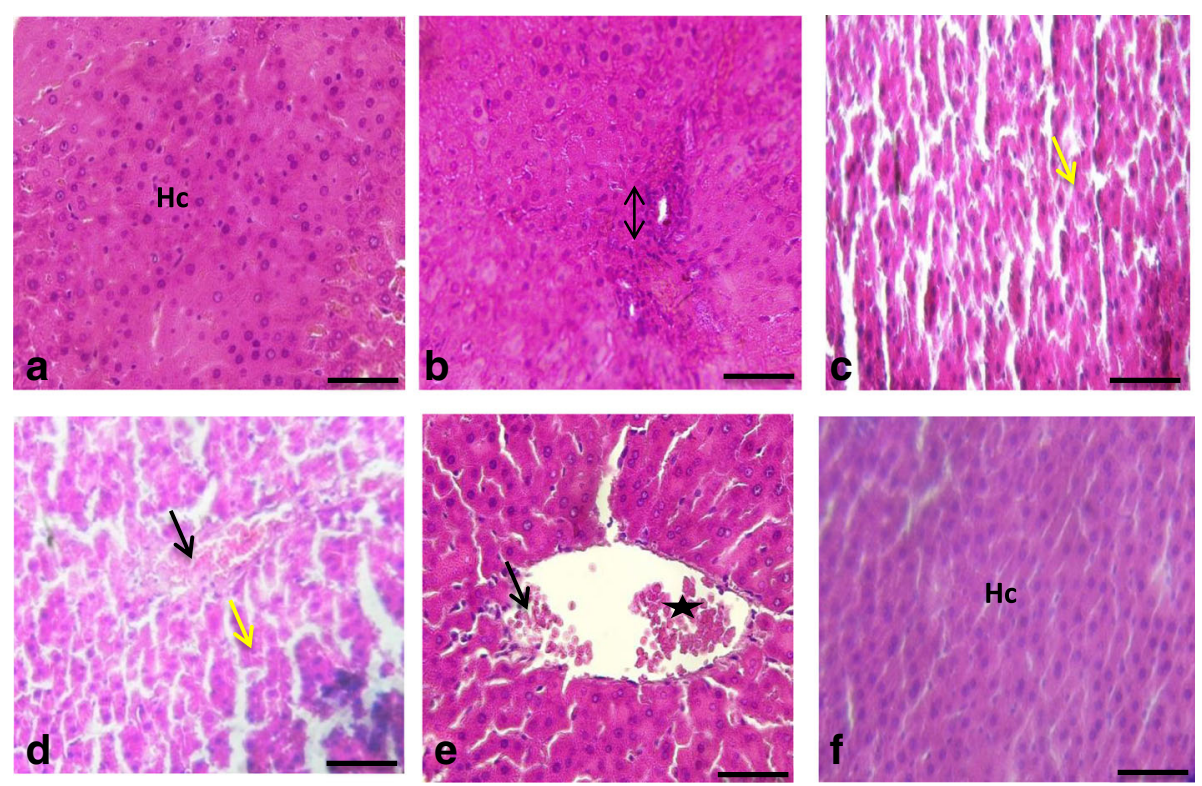

Fig. 3 Photomicrograph of H\&E sections of liver of control and AE treated rats showing normal hepatic cells with well-defined nuclei and cytoplasm $(\mathrm{Hc})$, normal hepatic vein(double arrow) $(\mathbf{a}, \mathbf{b})$. Section of Aluminum treated rat liver showing severe degenerative alterations with a necrotic anuclear hepatocytes (yellow arrows), infiltration of lymphocyte and Kupffer cells (black arrows), congestion and presence of necrotic area $\left(^{*}\right)(\mathbf{c}, \mathbf{d}, \mathbf{e})$. Section of Aluminum-AE treated rat liver showing a clear improvement compared to the control and AE groups $(\mathbf{f})$ with a reorganization of hepatocytes structure (Hc) (H\&E staining, magnification 150X and 300X, scale bar $=50 \mu \mathrm{m}$

enabling the regeneration of some anti-radical molecules from their oxidized forms (e.g., vitamins $\mathrm{C}$ or E); its decrease compromises hepatic function [52]. In our study, the decrease in the hepatic antioxidant defence system was confirmed by the decreased activities of antioxidant enzymes (SOD, CAT, and GPx), which are considered the first line of defence against oxidative damage [53].

Interestingly, co-administration of RAAE and $\mathrm{AlCl}_{3}$ significantly decreased the levels of MDA and carbonylated proteins while improving the level of GSH and the activities of antioxidant enzymes. The beneficial effects of RAAE could be due to the presence of bioactive molecules, including flavonoids, as previously reported [23, 27]. Flavonoids have been reported to prevent the depletion of GSH content using glutathione disulfide (GSSG) following ROS trapping [54, 55]. Additionally, flavonoids prevent lipid peroxidation through their redox properties, as highlighted by their ability to provide electrons and hydrogen atoms. Additionally, they could act by chelating transition metals, such as copper and iron $[56,57]$. These last results confirmed the efficacy of the $R$. alaternus extract in reducing/preventing the adverse effects of $\mathrm{AlCl}_{3}$ with an in vivo study. Indeed, rats receiving RAAE showed decreased hepatic histological damage induced by $\mathrm{AlCl}_{3}$. These results suggest hepatocyte cell repair and strengthens the beneficial use of RAAE to overcome the hepatic toxicity induced by $\mathrm{AlCl}_{3}$.

\section{Conclusions}

This study showed that the aqueous extract of $R$. alaternus attenuated oxidative damage and lipid peroxidation induced by $\mathrm{AlCl}_{3}$. The mechanism of this hepatoprotective effect could be linked to its antioxidant potential and its ability to increase the activity of antioxidant enzymes.

\section{Abbreviations}

RAAE: Rhamnus alaternus aqueous extract ; $\mathrm{AlCl}_{3}$ : Aluminum chloride; AST: Aspartate aminotransferase; ALT: Alanine aminotransferase; ALP: Alkaline phosphatase; LDH: Lactate dehydrogenase; MDA: Malonaldehyde; GSH: Reduced glutathione; SOD: Superoxide dismutase; GPx: Glutathione peroxidase; CAT: Catalase

\section{Authors' contributions}

Benzaid C: Conducting a research and investigation process, specifically, performing the experiments. Tichati L: collected and identified the plant, and performed the extraction of Rhamnus alaternus aqueous extract and phytochemical analysis. Trea F: Involved in antioxidants markers determination, histopathological analysis and participated in the discussion of results. Rouabhia M: Application of statistical and reviewing. Ouali K: supervised the project, wrote and submitted the manuscript, as well as responded to the reviewer's comments and suggestions. All authors have read and approved this manuscript before submission.

\section{Funding}

This research received no specific grant from any funding agency in commercial or not-for-profit sectors. This research was supported by the National Fund for Scientific Research of Algeria (Laboratory of Environmental Bio surveillance) and by the Ministry of Higher Education and Scientific Research of Algeria (PRFU project D01N01UN230120180020).

\section{Availability of data and materials}

All data and analyzed outcomes are available with the corresponding author if requested. 


\section{Declarations}

\section{Ethics approval and consent to participate}

The study was approved by the Ethical Committee of Directorate General for Scientific Research and Technological Development of the Algerian Ministry of Higher Education and Scientific Research under the ethical number of PNR ANDRS 8/423/345.

\section{Consent for publication}

All authors consent to the publication of the manuscript.

\section{Competing interests}

The authors declare that there are no conflicts of interest.

\section{Author details}

'Université Badji Mokhtar-Annaba-Département de Biochimie, Annaba, Algérie. ${ }^{2}$ Groupe de Recherche en Écologie Buccale (GREB), Faculté de médecine dentaire, Université Laval, 2420 rue de la Terrasse, QC G1V 0 A6 Quebec, Canada. ${ }^{3}$ Laboratory of Environmental Biosurveillance (LBSE), Department of Biology, Faculty of Sciences, Badji Mokhtar University, BP 12 Sidi Amar, 23000 Annaba, Algeria.

\section{Received: 6 August 2020 Accepted: 11 July 2021}

Published online: 23 July 2021

\section{References}

1. Tahari FZ, Lablack M, Hamadouche NA, Tahari Z, Aoues A. Protective effect of Haloxylon salicornicum on hepatic and renal functions of Wistar rats exposed to aluminum. Afr J Biotech. 2016;15(9):293-302.

2. Imam TS, Khalifa HA, Hussein MM, Ali HA. Aluminum-induced oxidative stress and hepato-renal impairment in male albino rats: possible protective trial with naringenin. Life Sci J. 2016:12(1s).

3. Klein GL. Aluminum toxicity to bone: A multisystem effect? Osteoporos Sarcopenia. 2019:5(1):2-5.

4. Kandimalla R, Vallamkondu J, Corgiat EB, Gill KD. Understanding Aspects of Aluminum Exposure in A Izheimer's Disease Development. Brain pathology. 2016;26(2):139-54

5. Exley C. The toxicity of aluminum in humans. Morphologie. 2016;100(329): $51-5$.

6. González MA, Bernal CA, Mahieu S, Carrillo MC. The interactions between the chronic exposure to aluminum and liver regeneration on bile flow and organic anion transport in rats. Biol Trace Elem Res. 2009;127(2):164.

7. Al-Kahtani MA. Renal damage mediated by oxidative stress in mice treated with aluminium chloride: protective effects of taurine. Journal of Biological Sciences. 2010;10(7):584-95.

8. Madhavi T. Ameliorative role of Bacopa phospholipid complex against aluminum induced neurotoxicity: Evaluation of aluminum accumulation by ICP-OES and cholinergic studies in albino rats. IJRAR. 2018;5(4):961-70.

9. Geyikoglu F, Türkez H, Bakir TO, Cicek M. The genotoxic, hepatotoxic, nephrotoxic, haematotoxic and histopathological effects in rats after aluminum chronic intoxication. Toxicol Ind Health. 2013;29:780-91.

10. Kumar V, Bal A, Gill KD. Susceptibility of mitochondrial superoxide dismutase to aluminium induced oxidative damage. Toxicology. 2009;255(3):117-23.

11. Ruipérez F, Mujika JI, Ugalde JM, Exley C, Lopez X. Pro-oxidant activity of aluminum: promoting the Fenton reaction by reducing Fe (III) to Fe (II). J Inorg Biochem. 2012;117:118-23.

12. Xu F, Liu Y, Zhao H, Yu K, Song M, Zhu Y. Li Y. Aluminum chloride caused liver dysfunction and mitochondrial energy metabolism disorder in rat. J Inorg Biochem. 2017;174:55-62.

13. El-Bakry H, El-Sherif G, Rostom RM. Therapeutic dose of green tea extract provokes liver damage and exacerbates paracetamol- induced hepatotoxicity in rats through oxidative stress and caspase 3-dependent apoptosis. Biomedicine pharmacotherapy. 2017;96:798-811.

14. Cheraghi $E$, Roshanaei $K$. The protective effect of curcumin against aluminum chloride-induced oxidative stress and hepatotoxicity in rats. Pharmaceutical Biomedical Research. 2019;5(1):11-8.

15. Ogunmoyole T, Dada I, Adebamigbe OA. Ameliorative potentials of Persea americana leaf extract on toxicants - induced oxidative assault in multiple organs of wistar albino rat. Clin Phytosci. 2021;7(27). https://doi.org/10.1186/ s40816-020-00237-1.
16. Crisponi G, Nurchi VM, Bertolasi V, Remelli M, Faa G. Chelating agents for human diseases related to aluminium overload. Coord Chem Rev. 2012; 256(1-2):89-104.

17. Al-Qayim MA, Mashi S. Renal effects of propolis and malic acid in Aluminum exposed male rats. App Sci Rep. 2014;5(1):26-30.

18. Othman MS, Fareid MA, Abdel Hameed RS, Abdel Moneim AE. The Protective Effects of Melatonin on Aluminum-Induced Hepatotoxicity and Nephrotoxicity in Rats. Oxid Med Cell Longev. 2020;2020:1-12.

19. Luo J, Li X, Li X, He Y, Zhang M, Cao C, Wang K. Selenium-Rich Yeast protects against aluminum-induced peroxidation of lipide and inflammation in mice liver. Biometals. 2018;31(6):1051-9.

20. Mokrane N, Kharoubi O, Tahari FZ, Guenzet A, Aoues A. The effect of Thymus vulgaris $L$. on renal and liver toxicity in wistar rats exposed to aluminum. Journal of Medicinal Plants Research. 2020;14(1):13-23.

21. Balgoon MJ. Assessment of the Protective Effect of Lepidium sativum against Aluminum-Induced Liver and Kidney Effects in Albino Rat. BioMed research international. 2019;2019(4516730):9. https://doi.org/10.1155/2019/4516730.

22. Bhouri W, Boubaker J, Kilani S, Ghedira K, Chekir-Ghedira L. Flavonoids from Rhamnus alaternus L. (Rhamnaceae): Kaempferol 3-O- $\beta$-isorhamninoside and rhamnocitrin 3-O- $\beta$-isorhamninoside protect against DNA damage in human lymphoblastoid cell and enhance antioxidant activity. South African journal of botany. 2012;80:57-62.

23. Ben Ammar R, Kilani S, Bouhlel I, Ezzi L, Skandrani I, Boubaker J, Ghedira K Antiproliferative, antioxidant, and antimutagenic activities of flavonoidenriched extracts from (Tunisian) Rhamnus alaternus L.: combination with the phytochemical composition. Drug Chem Toxicol. 2008;31(1):61-80.

24. Bhouri W, Sghaier MB, Kilani S, Bouhlel I, Dijoux-Franca MG, Ghedira K, Ghedira LC. Evaluation of antioxidant and antigenotoxic activity of two flavonoids from Rhamnus alaternus $L$. (Rhamnaceae): Kaempferol 3-O- $\beta$ isorhamninoside and rhamnocitrin 3-O- $\beta$-isorhamninoside. Food chemical toxicology. 2011;49(5):1167-73.

25. Moussi K, Nayak B, Perkins LB, Dahmoune F, Madani K, Chibane M. HPLCDAD profile of phenolic compounds and antioxidant activity of leaves extract of Rhamnus alaternus L. Ind Crops Prod. 2015;74:858-66.

26. Ammar RB, Bhouri W, Sghaier MB, Boubaker J, Skandrani I, Neffati A, DijouxFranca MG. Antioxidant and free radical-scavenging properties of three flavonoids isolated from the leaves of Rhamnus alaternus L. (Rhamnaceae): A structure-activity relationship study. Food Chem. 2009:116(1):258-64.

27. Boussahel S, Speciale A, Dahamna S, AmarY, Bonaccorsi I, Cacciola F, Cristani M. Flavonoid profile, antioxidant and cytotoxic activity of different extracts from Algerian Rhamnus alaternus L. bark. Pharmacogn Mag. 2015;11(Suppl 1):S102.

28. Berroukche A, Kahloula K, Sliman M, Denai I, Ammour K. Hepatoprotective effects of the decoction and macerated leaves of Rhamnus alaternus $L$. on rats exposed to carbon tetrachloride. J Pharmacogn Phytotherapy. 2015: 253-62.

29. Zhu KX, Lian CX, Guo XN, Peng W, Zhou HM. Antioxidant activities and total phenolic contents of various extracts from defatted wheat germ. Food Chem. 2011:126(3):1122-6.

30. Pourmorad F, Hosseinimehr SJ, Shahabimajd N. Antioxidant activity, phenol and flavonoid contents of some selected Iranian medicinal plants. Afr J Biotechnol. 2006;5(11).

31. Julkunen-Tiitto R. Phenolic constituents in the leaves of northern willows: methods for the analysis of certain phenolics. J Agric Food Chem. 1985; 33(2):213-7

32. Sánchez-Moreno C, Larrauri JA, Saura-Calixto F. A procedure to measure the antiradical efficiency of polyphenols. J Sci Food Agric. 1998;76(2):270-6.

33. Pan $Y$, Wang $K$, Huang $S$, Wang H, Mu X, He C, Huang F. Antioxidant activity of microwave-assisted extract of longan (Dimocarpus Longan Lour.) peel. Food Chem. 2008;106(3):1264-70.

34. Ismail A, Marjan ZM, Foong CW. Total antioxidant activity and phenolic content in selected vegetables. Food Chem. 2004;87(4):581-6.

35. Aita NAA. Hepatoprotective effect of Spirulina platensis against aluminum chloride induced liver damage in rats. Global Veterinaria. 2014;13(4):552-9.

36. Council of European Communities. Council instructions about the protection of living animals used in scientific investigations. Official Journal of the European Communities (JO86/609/CEE) L.358. 1986:1-18.

37. Jollow DJ, Mitchel JR, Zamppaglione Z, Gillette JR. Bromobenzene induced liver necrosis. Protective role of glutathione and evidence for 3,4bromobenzene oxide as the hepatotoxic metabolites. Pharmacology. 1974; 11:51-7. 
38. Buege JA, Aust SD. Microsomal lipid peroxidation. Methods Enzymol. 1984 105:302-10.

39. Levine RL, Garland D, Oliver CN, Amici A, Climent I, Lenz AG. Determination of carbonyl content in oxidatively modified proteins. Methods Enzymol. 1990;186:464-78.

40. Bradford M. A rapid and sensitive method for the quantities of microgram quantities of protein utilizing the principle of protein binding. Anal Biochem. 1976;72:248-54.

41. Beyer WF, Fridovich I. Assaying for superoxide dismutase activity. Anal Biochem. 1987;161:559-66.

42. Flohe L, Gunzler WA. Analysis of glutathione peroxidase. Methods Enzymol. 1984;105:114-21.

43. Aebi H. Catalase in vitro. Methods Enzymol. 1984;105:121-6.

44. Hould R. Techniques d'histopathologie et de cytopathologie. Ed Montréal Décarie Paris Maloine. 1984:225-7.

45. Tichati L, Trea F, Ouali K. The antioxidant study proprieties of Thymus munbyanus aqueous extract and its beneficial effect on 2, 4Dichlorophenoxyacetic acid-induced hepatic oxidative stress in albino Wistar rats. Toxicol Mech Methods. 2021;31(3):212-23.

46. Haddouchi F, Chaouche TM, Halla N. Phytochemical screening, antioxidant activities and hemolytic power of four Saharan plants from Algeria. Phytothérapie. 2016;1-9.

47. Albendea CD, Gómez-Trullén EM, Fuentes-Broto L, Miana-Mena FJ, MillánPlano S, Reyes-Gonzales MC, García JJ. Melatonin reduces lipid and protein oxidative damage in synaptosomes due to aluminium. J Trace Elem Med Biol. 2007;21(4):261-8.

48. Bakour M, Al-Waili NS, El Menyiy N, Imtara H, Figuira AC, Al-Waili T, Lyoussi B. Antioxidant activity and protective effect of bee bread (honey and pollen) in aluminum-induced anemia, elevation of inflammatory makers and hepato-renal toxicity. J Food Sci Technol. 2017;54(13):4205-12.

49. Akhtar MJ, Ahamed A, Kumar S, Khan MAM, Ahmad J, Alrokayan SA. Zinc oxide nanoparticles selectively induce apoptosis in human cancer cells through reactive oxygen species. Int J Nanomed. 2012;7:845-57.

50. Benchiha W, Mahroug S, Aoued L, Bouterfas K. Activité antihépatotoxique des extraits des feuilles de Rhamnus alaternus L. (Rhamnaceae). Phytothérapie. 2017;15(1):10-15.

51. Ghorbel I, Chaabane M, Elwej A, Boudawara O, Abdelhedi S, Jamoussi K, Zeghal N. Expression of metallothioneins I and II related to oxidative stress in the liver of aluminium-treated rats. Arch Physiol Biochem. 2016;122(4): 214-22

52. Valko M, Leibfritz D, Moncol J, Cronin MTD, Mazur M, Telser J. « Free radicals and antioxidants in normal physiological functions and human disease ». The International Journal of Biochemistry Cell Biology. 2007;39(1):44-84.

53. Al-Kahtani M, Abdel-Daim MM, Sayed AA, El-Kott A, Morsy K. Curcumin phytosome modulates aluminum-induced hepatotoxicity via regulation of antioxidant, Bcl-2, and caspase-3 in rats. Environ Sci Pollut Res. 2020;27(17): 21977-85.

54. Myhrstad MC, Carlsen H, Nordstrom O, Blomhoff R, Moskaug JJ. Flavonoids increase the intracellular glutathione level by transactivation of the gammaglutamylcysteine synthetase catalytical subunit promoter. Free Radic Biol Med. 2002;32:386-93.

55. Moskaug J, Carlsen H, Myhrstad MC, Blomhoff R. Polyphenols and glutathione synthesis regulation. Am J Clin Nutr. 2005;81:277S-283S.

56. Harborne JB, Williams CA. Advances in flavonoid research since 1992. Phytochemistry. 2000;55(6):481-504.

57. Falode JA, Akinmoladun AC, Olaleye MT. Ameliorative property of Kigelia africana crude and flavonoid leaf extracts on aluminum-induced hepatotoxicity in albino rats. Comp Clin Pathol. 2019;28(5):1495-506.

\section{Publisher's Note}

Springer Nature remains neutral with regard to jurisdictional claims in published maps and institutional affiliations.

\section{Submit your manuscript to a SpringerOpen ${ }^{\circ}$ journal and benefit from:}

- Convenient online submission

- Rigorous peer review

- Open access: articles freely available online

- High visibility within the field

- Retaining the copyright to your article

Submit your next manuscript at $\boldsymbol{\nabla}$ springeropen.com 